\title{
HUBUNGAN PERENCANAAN KEHAMILAN DAN DUKU NGAN SUAMI DENGAN TINGKAT PRENATAL DISTRESS
}

\author{
Yati Luaq Lung ${ }^{1}$, Desy Ayu Wardani ${ }^{2}$, Siti Kholifah ${ }^{3}$ \\ ${ }^{1-3}$ Program Studi Ilmu Keperawatan, Institusi Teknologi Kesehatan Institusi Teknologi Kesehatan \\ Kesehatan Dan Sains Wiyata Husada Samarinda \\ Email : yatiluaq@gmail.com, desyayuwardani@itkeswhs.ac.id, sitikholifah@,itkeswhs.ac.id
}

\begin{abstract}
ABSRAK
Latar Belakang : ibu hamil yang kehamilannya tidak direncanakan dan kurangannya dukungan suami menyebakan ibu hamil mengalami distress sebelum melahirkan sehingga kondisi fisik dan psikologis ibu sehingga berdampak lansung pada perkembangan janin. Tujuan : untuk mengetahui hubungan perencanaan kehamilan dan dukungan suami dengan tingkat prenatal distress. Metode : jenis penelitian yang dilakukan adalah penelitian kuantitatif dengan rancangan deskriptif analitik dengan pendekatan cross sectional dengan pengambilan sampel Consecutive sampling jenis Non probality sampling. sampel responden sebanyak 46 orang ibu hamil di puskesmas air puth samarinda . Hasil Penelitian : Hasil uji chi-square menunjukan bahwa tidak ada hubungan perencanaan kehamilan dengan tingkat prenatal distress dengan nilai $p$. value $=0,090>0,05$. Ada hubungan dukungan suami dengan tingkat prenatal distress dengan nilai p. value $0,013<0,05$. Kesimpulan : Ada hubungan Dukungan Suami dengan tingkat prenatal distress. Saran: Bagi peneliti selanjutnya diharapkan dapat melakukan penelitian dengan berdasarkan variabel yang berbeda, dengan jumlah sampel lebih banyak,tempat yang berbeda, desain yang tepat dan tepat.
\end{abstract}

Kata kunci : Perencanaan Kehamilan ${ }^{1}$, Dukungan suami ${ }^{2}$, Prenatal Distress ${ }^{3}$.

\section{PENDAHULUAN}

Prenatal Distress kemungkinan bisa terjadi pada sebagian besar ibu hamil. Prenatal distress kehamilan memberikan dampak secara langsung pada janin (cole, 2014). Kondisi psikologis yang terganggu dapat mempengaruhi kesehatan dan kesejahteraan fisik maupun emosional ibu dan bayinya. Kondisi psikologis ibu mempengaruhi proses perkembangan bayi (Malus et al.,2014). Dampak fisik dari ibu hamil terjadi preeklamsi berat, pertumbuhan janin yang buruk, distress pada janin bahkan kematian (Socolov et al.,2017

Kondisi ibu menunjukan perubahan emosi yang dapat menganggu kehamilan. Pengalaman teringat kehamilan yang sebelumnya tidak menyenangkan dan kurangnya dukungan keluarga dan perubuhan gaya hidup. Trimester II terjadi perubahan emosional dan berpusat pada kesan tubuh, seksual, dan janin yang dikandungnya. Trimester III, reaksi emosi meningkat, perhatian berubah pada 


finansial, persiapan ruang bayi, penting untuk dilakukan setiap pasangan
perlengkapan bayi, pengasuh dan orang tua. suami istri, (Kurniasih, 2010). Dampak merupakan faktor pencetus terjadinya reaksi psikologis yang mengarah pada gangguan emosional, (Ahmad Dahro, Buku psikologis kebidanan,2012).

Menurut WHO (2018) skala global, sebanyak 10\% ibu hamil dan $13 \%$ wanita hamil rentan mengalami gangguan psikologis, terutama depresi. Di Indonesia Menurut badan penelitian dan pengembangan kesehatan RI menemukan bahwa 23.9\%, angka kejadian gangguan psikologis pada ibu hamil. (Kemenkes 2013). Di Kalimantan Timur, berdasarkan Dinas Kesehatan Kota Samarinda 2019 sebanyak 728 kunjungan ibu hamil $87.36 \%$.

Perencanaan kehamilan mempengaruhi harapan ibu dalam menghadapi kehamilan dan persalinan (Louis et al,.2008). perencanaan kehamilan yang aman, sehat dan diinginkan merupakan faktor penting dalam upaya menurunkan angka kematian maternal. Menjaga jarak kehamilan menyelamatkan ibu dan bayi, serta memperbaiki kualitas hubungan keluarga. Perencanaan kehamilan kehamilan yang tidak direncankan atau tidak di inginkan mempengaruhi psikologis ibu hamil, kehamilan yang tidak direncanakan akan mempengaruhi tekanan sosial yang muncul dari lingkungan sekitar dan menjadi sumber distress pada ibu hamil, sedangkan kehamilan yang direncakan dan di inginkan akan menghasilkan keturunan yang sehat dan mempengaruhi hubungan keluarga menjadi lebih bahagia (susanti, 2008).

Dari studi pendahuluan yang dilakukan pada tanggal 15-16 desember 2019 peneliti membagikan kuesioner kepada 10 responden ibu hamil sebagian besar 6 responden ibu hamil kehamilannya terencana dan mendapat dukungan dari suami 4 diantara manyatakan kehamilan tidak terencana dan sebagian suami tidak mendukung kehamilanya dan merasa khawatir serta cemas akan kehamilannya.

\section{METODE PENELITIAN}

Jenis penelitian yang dilakukan adalah penelitian kuantitatif dengan 
Jurnal Keperawatan Wiyata

Volume 2, Nomor 1, Tahun 2021

ISSN 2774-4558 (Cetak)

ISSN 2774-9789 (Online)

rancangan penelitian analitik korelasi

dengan pendekatan cross sectional.

Pengambilan sampel dengan

Consecutive sampling dimana semua sampel

yang datang berurutan dan

memenuhi kriteria pemilihian dimasukan

dalam penelitian sampai jumlah sampel yang

diperlukan terpenuhi. Consecutive sampling

ini merupakan jenis Non probality sampling

yang memberikan populasi peluang yang

sama dilakukan penelitian yang memenuhi

kriteria inklusi dan kriteria eksklusi

\section{HASIL PENELITIAN}

\section{Karakteristi Responden}

Dalam penelitian ada beberapa kriteria responden yang menjadi kriteria yaitu

\section{1) . Usia Kehamilan}

\begin{tabular}{ccc}
\hline Usia Kehamilan & rekuensi & rsentase \\
\hline Trimester 1 & 16 & $34,8 \%$ \\
Trimester 2 & 20 & $43,5 \%$ \\
Trimester 3 & 10 & $21,7 \%$ \\
Total & 46 & $100 \%$
\end{tabular}

Berdasarkan tabel diatas dapat disimpulkan dari 46 responden, mayoritas usia kehamilan ibu paling banyak adalah pada trimester 2 sebanyak 20 responden dengan persentase $43,5 \%$.

\section{2.) Usia}

$\begin{array}{llll}\text { Usia Mean } & \text { Std. Minimum Maximum } \\ & \text { D } & & \\ & & \end{array}$

$20-40$

Tahun

Halaman 21-30

Tabel 4.2 diatas menunjukkan rata-rata usia responden sebanyak 24 Tahun dengan Std. Deviation berjumlah 3,804 sedangkan usia responden minimum sebanyak 20 Tahun dan usia responden maximum sebanyak 38 Tahun.

\section{3.) Pendidikan}

\begin{tabular}{ccc}
\hline Pendidikan & Jumlah & $\begin{array}{c}\text { Persentase } \\
(\mathbf{\%})\end{array}$ \\
\hline SMP & 8 & 17,4 \\
SMA & 30 & 65,2 \\
S1 & 8 & 17,4 \\
Jumlah & 46 & 100,0 \\
\hline
\end{tabular}

Berdasarkan tabel 4.3 diatas, diketahui pendidikan terakhir responden sebagian besar SMA berjumlah 30 orang (65\%). hal ini dikarenakan sebagian besar responden mulai bekerja setelah lulus SMA.

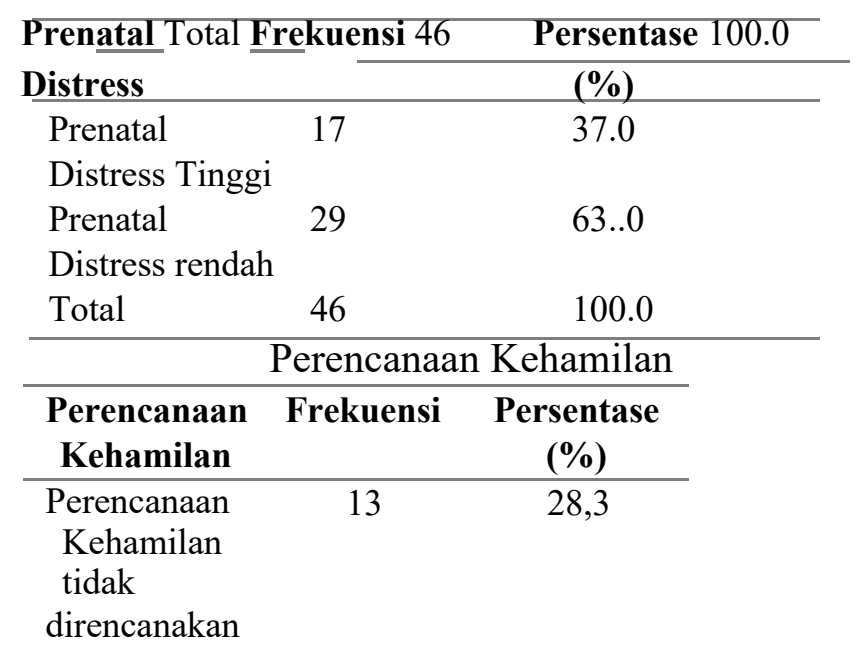


Jurnal Keperawatan Wiyata

Volume 2, Nomor 1, Tahun 2021

ISSN 2774-4558 (Cetak)

ISSN 2774-9789 (Online)

Halaman 21-30

Perencanaan $33 \quad 71,7$

kehamilan

direncanakan

Total

46

100.0

Berdasrakan Tabel 4.5 didaptkan distribusi

Perencanaan Kehamilan tidak direncanakan di wilayah kerja UPT Puskesmas air putih samarinda menunjukan frekuensi 13 orang $(28,3 \%)$ dan perencanaan kehamilan direncanakan sebanyak 33 ( 71,7\%). 8). Dukungan Suami

\begin{tabular}{lll}
\hline $\begin{array}{l}\text { Dukungan } \\
\text { suami }\end{array}$ & Frekuensi & $\begin{array}{l}\text { Persentase } \\
(\%)\end{array}$ \\
\hline $\begin{array}{l}\text { Kurang } \\
\text { Mendukung }\end{array}$ & 19 & 41,3 \\
Mendukung & 27 & 58,7 \\
Total & 46 & 100.0 \\
\hline
\end{tabular}

Berdabersarkan Tabel 4.6 didapatkan distribusi

Dukungan Suami diwilayah kerja UPT

Puskesmas Air Putih Samarinda dengan kurang mendukung sebanyak 19 orang ( $41, \%)$, mendukung sebanyak 27 orang $(58,7,5 \%)$.

9). Prenatal Distress

Berdasarkan Tabel 4.6 didapatkan distribusi Prenatal Distress di Wilayah kerja UPT Puskesmas air putih samarinda menunjukan frekuensi terbanyak pada ibu hamil dengan tingkat prenatal distress tinggi yaitu sebanyak 17 orang $(37 ., 0 \%)$ prenatal distress rendah sebanyak 29 orang $(63,0 \%)$.

\section{PEMBAHASAN}

\section{Perencanaan Kehamilan}

Berdasarkan tabel 4.5 hasil analisis perencanaan kehamilan diperoleh bahwa perencanaan kehamilan yang tidak direncanakan sebanyak 13 
Jurnal Keperawatan Wiyata

Volume 2, Nomor 1, Tahun 2021

ISSN 2774-4558 (Cetak)

ISSN 2774-9789 (Online)

Halaman 21-30

prekonsepsi. Kehamilan yang tidak

direncanakan atau kehamilan yang tidak

diinginkan menjadi salah satu faktor

yang memengaruhi harapan ibu dalam

menghadapi persalinan. Kondisi ini

akan menghambat ibu dalam

mempersiapkan persalinan (Kost,

Landry dan Darroch, 1998).

2. Dukungan Suami Berdasarkan tabel

4.6 diperoleh hasil analisis dukungan suami dengan tingkat prenatal distress di puskesmas air putih samarinda didapatkan ibu hamil dengan dukungan suami kurang mendukung sebanyak 19 responden, sedangkan Dukungan suami yang Mendukung seabian besar berjumlah 27 responden. Hal ini sejalan dengan penelitian yang dilakukan oleh fitri widiarti (2017) dengan hasil adanya hubungan antara dukungan suami dengan tingkat kecemasan pada ibu hamil. Menurut Teori Nurheni(2008) menyatakan bahwa dukungan suami sangat di perlukan ibu hamil untuk meningkatkan kesejahteraan psikologis dan penyesuaian diri serta mengurangi stres dan kecemasan selama kehamilan dan meningkatkan pemeliharaan kesehatan fisik selama kehamilan.

\section{Prenatal Distress}

Berdasarkan Tabel 4.7 didapatkan data Prenatal Distress rendah sebanyak 17 responden sedangkan Prenatal distress tinggi sebagian besar berjumlah 29 responden . Hal ini sejalan dengan Penelitian ike puspasari ayu (2019). Distress prenatal adalah gangguan emosional yang terjadi pada wanita hamil (Arch, 2013). Kondisi tekanan pranatal berpengaruh pada persalinan. Hormon stres, seperti adrenalin berinteraksi dengan reseptor di otot rahim dan menghambat kontraksi dan memperlambat persalinan. Distress dapat benar-benar membahayakan kehamilan karena merupakan prediktor akurat kesehatan ibu selama persalinan, bayi baru lahir dan menstruasi setelah melahirkan. Pada wanita hamil yang memiliki tingkat tekanan pranatal yang tinggi dapat meningkatkan risiko kelahiran prematur bahkan keguguran (Denis, Michaux, dan Callahan, 2012).

Hubungan Perencanaan Kehamilan Dengan Tingkat Prenatal Distress. Berdasarkan Tabel 4.8 hasil penelitian didapatkan bahwa responden yang perencanaan kehamilan yang tidak direncanakan sebanyak 2 orang sedangkan ibu hamil dengan perencanaan kehamilan direncanakan sebanyak 11 orang. Pada ibu hamil yang perencanaan kehamilan 
Jurnal Keperawatan Wiyata

Volume 2, Nomor 1, Tahun 2021

ISSN 2774-4558 (Cetak)

ISSN 2774-9789 (Online)

Halaman 21-30

direncanakan sebanyak 15 orang sedangkan pada ibu hamil dengan perencanaan kehamilan tidak direncanakan terhadap prenatal distress tinggi didapatkan sebagian bersar berjumlah 18 orang. Hasil uji statistic nilai probabilitis (p) sebesar $0,090>0,05$ karena nilai $p$ besar dari nilai a, Ho tidak diterima Ha diterima maka tidak ada hubungan antara perencanaan kehamilan dengan tingkat prental distress dipuskesmas air putih samarinda. Hasil penelitian tidak sejalan dengan penelitian yang dilakukan oleh Veronika Yeni Rahmawati (2019) yang menunjukan bahwa perencanaan kehamilan merupakan perencanaan berkeluarga yang optimal melalui perencanaan yang aman, sehat, dan diinginkan merupakan salah satu faktor penting upaya, menurunkan angka kematian maternal. Menjaga jarak kehamilan tidak hanya menyelamatkan ibu dan bayi dari sisi kesehatan, namun juga memperbaiki kualistas hubungan psikologi keluarga ( Mirza, 2008).

Perencanaan kehamilan merupakan upaya individu untuk mencapai suatu proses dalam hidupnya dengan pasangannya yaitu memiliki mewujudkan harapan ibu hamil remaja dalam persalinan agar tercipta pengalaman persalinan yang positif. Terlebih, hal yang paling penting dilakukan adalah mempromosikan usia ideal ibu hamil sehingga dapat mengurangi dampak buruk dari kehamilan remaja. Untuk itu diperlukan penelitian lebih lanjut berupa intervensi yang dapat dilakukan terkait promosi tentang perencanaan kehamilan beserta pasangan agar mendapatkan gambaran tentang proses persalinan.

Dampak dari stressnya ibu hamil dengan kehamilan yang tidak di rencanakan akan berpengaruh terhadap fisik dan psikis baik ibu maupun janinnya. Ibu yang menderita stress akan mengalami peningatan lepasnya hormon-hormon stres sehingga menyebabkan gangguan aliran darah di dalam rahim dan mengakibatkan lemahnya kontraksi otot rahim. Kejadian tersebut menyebabkan makin lamanya proses persalinan (partus lama) dan resiko sectio caesaria sebanyak 54,8\%. Sedangkan resiko untuk bayi dapat menyebabkan kelahiran prematur, melahirkan bayi dengan berat badan lahir rendah (BBLR), kegawatan (fetal distress) dan dalam jangka panjang berkaitan dengan gangguan prilaku dan emosi anak(Umy Hanifah,2010).

Menurut Asumsi peneliti Ibu Hamil dengan prenatal distress yang tinggi akan mempengaruhi kondisi psikologis 
Jurnal Keperawatan Wiyata

Volume 2, Nomor 1, Tahun 2021

ISSN 2774-4558 (Cetak)

ISSN 2774-9789 (Online)

Halaman 21-30

dan fisik bagi ibu hamil dan janin, dikarenakan kurangnya dalam mempersiapkan kehamilan. Hubungan

\section{Dukungan Suami Dengan}

\section{Tingkat Prenatal Distress.}

Berdasarkan Tabel 4.9 hasil penilitian didapatkan data dukungan suami kurang Mendukung sebanyak 3 responden dengan dan sebaian besar sebanyak 16 responden sedangkan yang mendapat dukungan suami berjumlah 14 responden dan sebagianmberjumlah 13 responden. (Hasil analisis statistic nilai probabilitis (p) sebesar $0,013<0,05$ karena nilai $\mathrm{p}$ kecil dari nilai a, Ha diterima dan $\mathrm{H} 0$ tidak diterima maka ada hubungan antara dukungan suami dengan tingkat prental distress dipuskesmas air putih samarinda. Hasil penelitian ini Sejalan dengan penelitian ini sesuai dengan hasil penelitian Arifin (2015) dukungan suami terhadap istri dapat menyebabkan adanya ketenangan batin dan perasaan senang dalam diri istri, sehingga istri akhirnya menjadi lebih mudah menyesuaikan diri dalam situasi kehamilan ini. Dukungan suami penting untuk kehamilan istri karena terkadang istri dihadapkan pada situasi ketakutan dan kesendirian,sehingga

suami diharapkan untuk selalu memotivasi dan menemani ibu hamil. Selain itu dukungan yang diberikan suami selama istri hamil juga dapat mengurangi kecemasan serta mengembalikan rasa percaya diri calon ibu dalam mengalami kehamilan dan menghadapi persalinannya. Hal ini sesuai dengan konsep suami siaga bahwa kewaspadaan suami mengenai tanda bahaya kehamilan dan kesiapan suami mendampingi istri ke tempat pelayanan kesehatan untuk pemeriksaan kehamilan memang diharapkan pada setiap kunjungan pemeriksaan kehamilan, para suami selalu mendampingi istri sehingga mereka tahu kondisi kehamilan istrinya. Sesuai dengan teori Hamidah dan Syafrudin (2009, hlm 227) bahwa suami siaga adalah suami yang siap menjaga istrinya yang sedang hamil, menyediakan tabungan bersalin, serta memberikan kewenangan untuk menggunakannya apabila terjadi masalah kehamilan.

Menurut jurnal Muhadiono, widyo subagyo dan Wahyuningsih (2015) dengan jelas menunjukan pentingnya dukungan suami dalam menghadapi persalinan. Meneurut sarafino (2006), 
Dukungan suami merupakan sikap, tindakan penerimaan terhadap anggota keluarganya ( $\mathrm{Ibu}$ ) yang berua dukungan informasional, penilian, instrumental dan dukungan emosional (friedman,2010). dukungan suami adalah suatu bentuk kenyamanan, perhatian, penghargaan, atau pun bantuan yang diterima individu dari orang yang berarti, baik secara perorangan maupun kelompok. berdasarkan teori yang dikemukan Asrinah bagi ibu hamil akan mempererat hubungan antara anak ayah dan suami istri. Dukungan yang diperoleh ibu hami akan membuatnya tenang dan nyaman dalam kehamilannya untuk mewujudkan kehamilan yang sehat dan bahagia

( Asrinah,2010).

Dari penelitian sebelumnya widianingrat (2010) dikutip dari oleh Rahmawati (2016) menjelaskan bahwa dukungan suami yang diberikan berupa materi,informasi, penghargaan, yang berguna untuk meningkatkan keadaan fisik dan psikologis istri. Dukungan suami diperkirakan menjadi penyebab utama terjadinya depresi posfartum. hal ini dikarenakan suami merupakan orang terdekat yang bertanggung jawab memfasilitasi timbulnya rasa nyaman, aman, dan rasa dihormati, rasa berharga, rasa dibutuhkan, kuat dan semangat untuk menyelsaikan kehamilanya dan persalinan dengan baik dann penuh kebahagiaan.akibatnya ibu mempu mengadaptasi perubahan emosi dan terhindar dari persaaan depresi. Secara psikologis dukungan suami tersebut membuat istri atau ibu merasa nyaman, berharga dan dibutuhkan sehingga timbul rasa semangat, percaya diri dalam menhadapi persalinannya. sebaliknya ibu yang tidak memproleh dukungan terutama suami akan merasa diabaikan, tidak berharga, merasa dalam bahaya, merasa diperlakukan tidak hormat,merasa dikucilkan, atau dianggap remeh yang pada akhirnya memicu stress selama kehamilan (Simmkin at.al..2005).

Peneliti berasumsi pentingnya dukungan suami terhadap terhadap kehamilan istri dapat meningkatkan kesejahteraan psikologis dan penyesuaian diri serta mengurangi stres dan kecemasan selama kehamilan dan meningkatkan dan memelihara kesehatan fisik selama kehamilan. 
Jurnal Keperawatan Wiyata

Volume 2, Nomor 1, Tahun 2021

ISSN 2774-4558 (Cetak)

ISSN 2774-9789 (Online)

Halaman 21-30

KESIMPULAN

1. Berdasarkan hasil penelitian di dapatkan bahwa karakteristik responden dalam penelitian ini adalah bahwa rata-rata usia ibu hamil 27 yang artinya rata-rata ibu hamil berada pada kategori dewasa tengah,

2. hasil uji statistic nilai probalitas (p) sebesar 0,090 > 0,05 yang berarti tidak ada hubungan perencanaan kehamilan dengan tingkat prenatal distress.

3. Dukungan Suami dengan tingkat Prenatal Distress dipuskesmas air putih samarinda dengan ibu hamil yang kurang mendapat dukungan sebagian kecil , sedangkan sebagian besar paling mendapat mendapat dukungan dari suami

\section{DAFTAR PUSTAKA}

Ahmad Dahro, (2012) Buku PSikologis Kebidanan: perilaku wanita untuk kesehatan Jakarta : Salemba Medika Arikunto, S. 2010. Prosedur Penelitian suatu Pendekatan Praktek. Rineka Cipta. Jakarta

Arantika M. Pratiwi, S.ST.,M.Kes (2019)

$$
\text { Patologi kehamilan: }
$$

Memahami Berbagai Penyakit dan komplikasi kehamilan Yogyakarta : Pustaka Baru Press
Aisyah . R, D. and Fitriyani (2016) Hubungan frekuensi ANC, Dukungan Suami, pekerjaan dengan anemia pada ibu hamil ; The 4 th university Research colloquium 2016 (2013),pp 83-89

Atikah, P and Asfuah, S. (2009) Gizi untuk kebidanan. Yogyakarta :Muha Medika

Bobak, Lowdemik and Jensen (2005) Buku Ajar Keperawatan Maternitas, $4^{\text {th }}$ edn Jakarta:ECG

Dr. Miriam Stoppard (2013) panduan mempersiapkan kehamilan dan kelahiran, Yogyakarta : Pustaka Pelajar

Alligood Martha Raile (2017) Pakar Teori Keperawatan, ed: 8 Volume 2, Indonesia: Elsevier

Puspasari Ike (2019) journal Usia Maternal Sebagai Dominan Yang Mempengaruhi Kecepatan Prenatal Primigravida.

Hidayat Monna Maharani (2018) journal hubungan kepuasaan dukungan social dengan Kondisi psikologis ibu

McDoNALD Nicola v. winson Sandra (2008) Kamus kebidanan bergambar edisi: bahasa Indonesia, Jakarta : EGC

Sugiyono, (2015). Metodologi Penelitian (Pendekatan Kuantitatif, Kualitatif Dan $R \& D)$. Renike Cipta

Notoatmojo, S(2010). Metodologi Penelitian

Kesehatan. Jakarta : Reneka Cipta

Notoatmodjo, S, 2015.Metode Penelitian Kesehatan.Jakarta: Rineka Cipta.

Nursalam, (2017). Metodologi Penelitian Ilmu Keperawatan, Edisi 4. Jakarta: Selemba Medika

Nursalam, (2017). Metodologi Penelitian Ilmu Keperawatan, Edisi 4. Jakarta: Selemba Medika 
Jurnal Keperawatan Wiyata

Volume 2, Nomor 1, Tahun 2021

ISSN 2774-4558 (Cetak)

ISSN 2774-9789 (Online)

Nursalam. (2008). Konsep dan Penerapan

Metodelogi Penelitian Il

mu Keperawatan. Jakarta:

Salemba Medika

Anindita, R,. (2012). Dukungan

Suami Terhadap Istri yang

Sedang Hamil. Psikologi Kesehatan

Nursalam. (2014). Metodologi Penelitian Ilmu Keperawatan: Pendekatan Praktis. Jakarta: Salemba Medika

Baiq A.A., Dyah K.T., Miftakhul M. E. (2014). Hubungan Dukungan Suami dengan Kepatuhan Kunjungan Antenatal Care (ANC) pada Ibu Hamil Trimester III di Rumah Bersalin Pemerintah Kota Malang. Article Journal

Dahlan, Sopiyudin. (2015). Statistik untuk Kedokteran dan Kesehatan. Jakarta: Epidemiologi Indonesia.

Susanti N.N. (2008). Psikologi Kehamilan. Jakarta: Penerbit Buku Kedokteran EGC

Sugiyono. (2015). Metode Penelitian Kuantitatif, Kualitatif, dan R\&D. Bandung: Alfabeta

Maharani, T.I. (2008). Hubungan Antara Dukungan Suami Dan Kecemasan Dalam Menghadapi Persalinan Pada Ibu Hamil Trimester Ketiga. Jurnal Ilmiah Psikologi. Volume 2, No.

Diakses pada 7 Desember 2018.

Kholil, L R. (2010). Kesehatan Maternal. Purwokerto: Fajar Media Press. Kusumawati F dan Hartono Y. (2008). Buku Ajar Keperawatan Jiwa. Jakarta:

Salemba Medika.

Musbikin, I. (2006). Panduan Bagi Ibu

Hamildan

Yogyakarta:

Melahirkan.

Pustaka Manuaba. (2007). Buku

Pengantar Kuliah Obstetri.

Jakarta.

Sastroasmoro dan Ismael (2014). Dasardasar Metodologi Penelitian Klinis Edisi Ke-5. Jakarta : Sagung Seto.

Sheeba, B., A. N., Metgud, C. S., Murthy, and G. V. S. (2019). Prenatal Depression and Its Associated Risk Factors Among Pregnant Women in Bangalore: A Hospital Based Prevalence Study. Journal Article.

Siti, S.R., (2017). Faktor Yang Berhubungan Dengan Kesiapan Persalinan Pada Ibu

$$
\begin{aligned}
& \text { Hamil Trimester III } \\
& \text { Di }
\end{aligned}
$$

Puskesmas Pleret Bantul. Fakultas Ilmu Kesehatan. Universitas Aisyiyah Yogyakarta. Journal Article.

Sumiati. (2015). Faktor-faktor Yang Mempengaruhi Kesiapan Ibu Hamil Dalam Menghadapi Persalinan Di Ruang Bersalin Rumah Sakit Umum Daerah Labuang Baji

Makassar. Journal Article, 5

Sumi, Y. (2015). Hubungan Dukungan Sosial Petugas Kesehatan Dengan Kepuasan Pelayanan Antenatal Care Pada Ibu Hamil di Puskesmas Wonorejo Samarinda. 